\title{
The influence of donor nucleus source on the outcome of zebrafish somatic cell nuclear transfer
}

\author{
KANNIKA SIRIPATTARAPRAVAT ${ }^{1}$, BOONYA PINMEE2 ${ }^{2}$ EUN-AH CHANG ${ }^{2}$, JUAN D. MUÑOZ3 \\ KOICHI KAWAKAMI ${ }^{5}$ and JOSÉ B. CIBELLI*,1,2,4,6 \\ ${ }^{1}$ Comparative Medicine and Integrative Biology Program, College of Veterinary Medicine, ${ }^{2}$ Department of \\ Animal Science, ${ }^{3}$ Department of Crop and Soil Sciences, and ${ }^{4}$ Department of Physiology, Michigan State \\ University, Michigan, USA, ${ }^{5}$ Division of Molecular and Developmental Biology, National Institute of \\ Genetics, and Department of Genetics, Graduate University for Advanced Studies (SOKENDAl), Mishima, \\ Japan, and ${ }^{6}$ Programa Andaluz de Terapia Celular y Medicina Regenerativa, Andalucia, Spain
}

\begin{abstract}
The success of nuclear reprogramming following somatic cell nuclear transfer (SCNT) is thought to depend on factors present in the egg. Little is known about the role - if any - played by the somatic cell type on the outcome of the procedure. We tested whether cells of different lineages might have different capacities for reprogramming following SCNT, comparing cells isolated from five different tissues of transgenic zebrafish for their developmental potential when used as SCNT donor cells. We used transgenic zebrafish lines expressing green fluorescence protein under an endogenous tissue-specific promoter: HGn62A-skin, HGn28A-skin, HGn8Eheart, HG21C-fin and notochord and HGn30A-hatch gland. We analyzed the efficiency of cloning, as measured by reconstructed embryos that developed up to the hatched-fry stage. Specifically, donor cells of fin and notochord origin yielded the best rate of cloned fish production. All of the other cell types used were capable of producing cloned fish, albeit with significantly lower efficiency. These results indicate that the type of zebrafish cells used for SCNT can influence the outcome of the procedure. Future epigenetic analysis of these cells will help determine specific chromatin profiles in somatic cells that have an impact on nuclear reprogramming procedures.
\end{abstract}

KEY WORDS: somatic cell nuclear transfer, zebrafish, cloning, donor nucleus source, epigenetics

\section{Introduction}

As a cell differentiates, its developmental potential is known to become more restrictive. Following somatic cell nuclear transfer (SCNT), cells can be reprogrammed to an embryonic state at different efficiencies, depending on the type of cell or tissue origin. We have learnt from mouse experiments that the easiest cells to reprogram are blastomeres from a morula; however, efficiency progressively declines when cells from the inner cell mass and tissue-specific cells are used (Gurdon and Melton, 2008; Hochedlinger and Jaenisch, 2006; Thuan et al., 2010; Wakamatsu, 2008). Side-by-side comparisons of different cell types showed that ESCs were more amenable to cloning than somatic fibroblasts (Rideout et al., 2000); and even among different somatic cell populations, the variations in cloning efficiency were significant (Oback, 2009; Oback and Wells, 2007). In amphibians, adult frogs were obtained when donor nuclei were isolated from blas- tomeres (Gurdon et al., 1958) and embryonic-intestinal cells (Gurdon and Uehlinger, 1966), but only tadpoles were produced using adult cells as donor nuclei (Gurdon et al., 1975; Laskey and Gurdon, 1970). This evidence points towards the existence of a cell-to-cell variability that can be attributed to the epigenetic state that defines the phenotype of a given cell.

Effective nuclear reprogramming requires shutting down somatic-cell-specific gene expression and turning on embryoniccell-specific genes in a carefully choreographed manner. In SCNT, errors of nuclear reprogramming were observed in almost all species cloned (Cibelli et al., 2002). When muscle cells were used as donor nuclei to clone mice, the GLUT4 glucose trans-

\footnotetext{
Abbreviations used in this paper: CSOF, chinook salmon ovarian fluid; GFP+, green fluorescence protein positive; hpf, hour postfertilization; SCNT, somatic cell nuclear transfer.
}

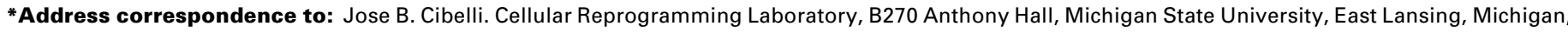
48824 USA. Tel: +1-517-432-8250. Fax: +1-517-432-8742. e-mail: cibelli@msu.edu - web: www.reprogramming.net
} 
porter gene continued to be active in early embryos (Gao et al., 2003). Furthermore, the pluripotency-related gene, Oct 4, is expressed incorrectly in the majority of the cloned embryos produced using nuclei from cumulus cells (Boiani et al., 2002). In frogs, the tissue-specific gene expression of a donor cell was found to persist in cloned embryos, a phenomenon known as epigenetic memory ( $\mathrm{Ng}$ and Gurdon, 2005, 2008). Despite these abnormal patterns of gene expression, a small population of cloned animals can develop into seemingly healthy adults.

It has been suggested that one of the most important steps towards successful SCNT is the selection of a population of donor nuclei that are intrinsically more reprogrammable by the recipient oocyte (Santos and Dean, 2004). We have evidence indicating that the cell donor is responsible for variations in the efficiency of SCNT (Kato et al., 2000; Wakayama and Yanagimachi, 1999), yet it is inconclusive (Oback, 2009). Work done in our laboratory has shown that, in zebrafish, the efficiency of producing cloned hatched-fry can be 6 to 13 percent when donor cells are freshly isolated from the embryonic tail-bud but much less when adult tail fin cells are used (Siripattarapravat et al., 2009b). Based on this evidence, we hypothesized that the efficiency of nuclear reprogramming in zebrafish varies from one tissue-specific cell to another. In other words, cells from different lineages could have different developmental potential when used as donor cells for SCNT.

To test this hypothesis, we proposed to evaluate the efficiency of cloning zebrafish (as measured by reconstructed embryos that develop to normal hatched-fry stage) when using donor cells derived from three different sources: ectoderm, mesoderm, and endoderm. We used transgenic zebrafish expressing green fluorescence protein (GFP) under a very 'tight' endogenous tissue-specific promoter (Fig. 1) (Nagayoshi et al., 2008). All transgenic lines were generated with the Tol2-mediated enhancer trap method developed by the Kawakami lab (Nagayoshi et al., 2008). These fish expressed GFP in a tissuespecific manner at approximately 24 hours postfertilization (hpf), allowing the rapid identification of these live cells.

We report here the cloning efficiency of five different zebrafish cell types, using five different transgenic lines: 1) HGn62A-skin (ectoderm), 2) HGn28Askin (ectoderm), 3) HGn8E-heart (mesoderm), 4) HG21C-fin/notochord (mesoderm) and 5) HGn30Ahatch gland (endoderm) (Nagayoshi et al., 2008). The results showed that GFP+ cells from the HG21C line were much more amenable to nuclear reprogramming than those from the other lines.

\section{Results}

We performed SCNT as previously described (Siripattarapravat et al., 2009b), except that we took the donor cells from embryos $24 \mathrm{hpf}$ and selected GFP+ cells prior to nuclear transfer (Fig. 1). We observed the developmental capacity of cloned embryos derived from donor cells from different sources (Table 1 and Fig. 2). All cell types used yielded

cloned embryos, albeit at different rates of developmental capacity and degrees of normality. We were able to clone adult zebrafish from donor cells of HGn28A and HGn8E. After we back-crossed them with the wild-type strain, the offspring of these clones were normal and carried lineage-specific GFP+ gene from their cloned parental lines (Fig. $1 \mathrm{~F}, \mathrm{G}$ ).

We recorded the developmental rates of cloned embryos at seven stages: blastula; germ ring (entering gastrulation); 90 percent epiboly (complete gastrulation); day 1 (complete segmentation); day 4 (hatched fry); eating fry; and adult (Kimmel et al., 1995). Cloned embryos were classified according to their morphology and recorded as either normal embryos or total embryos (including abnormal counts). Results are shown in Table 1 and Fig. 2. At the blastula stage, cell division is the major event, with cells undergoing approximately 10 to 11 cell divisions before entering the midblastula transition, when the cell cycle is no longer homogeneous and lengthens; at this point, zygotic gene transcription starts (Kimmel et al., 1995). Except for HGn8E, which had an 18 percent rate, approximately 40 percent of cloned embryos completed development to normal blastulae. At this stage, the abnormal cloned embryos were partial blastulae. At the gastrulation stage, cells start to differentiate, migrate, and form the germ ring (GR). Only 5 percent of cloned embryos from the HGn62A, HGn30A, and HGn8E lines developed to normal GR, while 12 percent of $\mathrm{HGn} 28 \mathrm{~A}$ and 20 percent of $\mathrm{HG} 21 \mathrm{C}$ did so. The
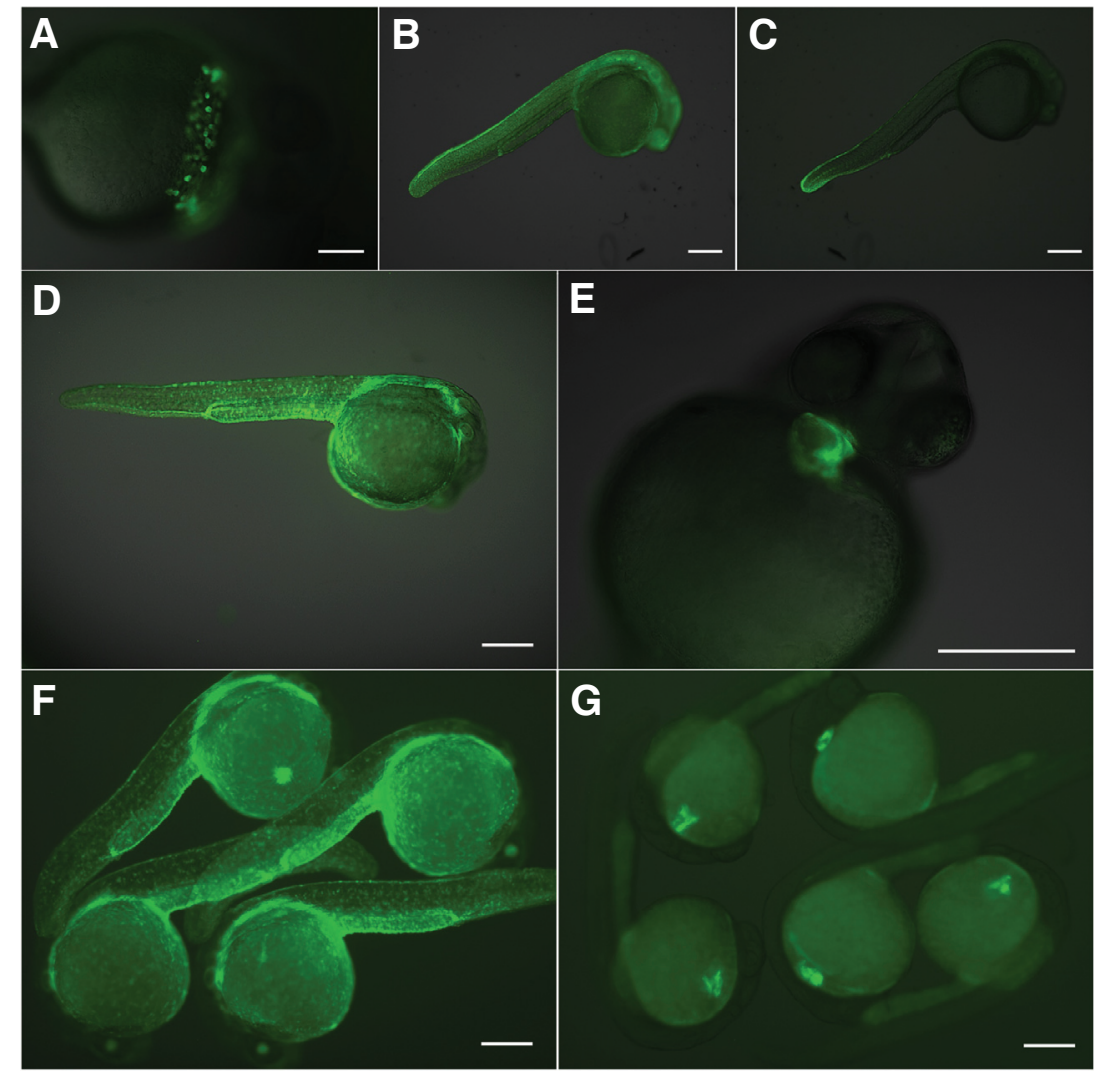

Fig. 1. GFP+ donor embryos and offspring of cloned zebrafish. Tissue-specific GFP+ embryos at 24 hours postfertilization: HGn30A (A), HGn62A (B), HG21C (C), HGn28A (D), and HGn8E (E); these were the sources of GFP+ donor cells (Nagayoshiet al., 2008). Back-crossed with wild-type strain, offspring of cloned zebrafish from HGn28A GFP+ donor cells (F) and HGn8E GFP+ donor cells (G) of the same age. Scale bar, 250 um. 
TABLE 1

EFFICIENCY OF ZEBRAFISH SCNT FROM GFP+ DONOR CELLS OF DIFFERENT LINEAGES

\begin{tabular}{|c|c|c|c|c|c|c|c|c|c|}
\hline \multirow[b]{2}{*}{ Donor $\mathrm{G}_{+}$} & \multirow[b]{2}{*}{ NT } & \multirow{2}{*}{$\begin{array}{l}\text { No. } \\
\text { eggs }\end{array}$} & \multicolumn{7}{|c|}{ Developmental stages - Number of embryos (\%mean+SE) } \\
\hline & & & Blastula & Germ Ring & 90\%Epiboly & 1 day & 4 days & Live (Eat) & Live (Adult) \\
\hline HGn62A-N & 4 & 290 & $107(37.33+6.26)$ & $18(6.60+3.64)$ & $9(3.23+1.31)$ & $1(0.38+0.38)$ & $1(0.38+0.38)$ & $1(0.38+0.38)$ & 0.00 \\
\hline HGn62A-T & & & $180(61.85+3.00)$ & $26(9.36+3.86)$ & $15(5.30+1.93)$ & $12(4.27+1.94)$ & $2(0.74+0.43)$ & $1(0.38+0.38)$ & 0.00 \\
\hline HGn30A-N & 3 & 225 & $95(37.04+18.57)$ & $11(4.48+1.24)$ & $7(2.68+1.40)$ & $1(0.39+0.39)$ & $1(0.39+0.39)$ & 0.00 & 0.00 \\
\hline HGn30A-T & & & $146(58.88+18.79)$ & $39(15.22+7.01)$ & $18(6.84+3.46)$ & $8(3.05+1.53)$ & $2(0.78+0.78)$ & 0.00 & 0.00 \\
\hline HGn28A-N & 3 & 225 & $79(35.10+1.24)$ & $29(12.38+3.90)$ & $13(5.60+2.80)$ & $5(2.13+1.08)$ & $2(0.95+0.95)$ & $2(0.95+0.95)$ & $1(0.48+0.48$ \\
\hline HGn28A-T & & & $116(52.21+6.43)$ & $35(15.15+3.65)$ & $17(7.51+3.32)$ & $9(3.95+2.10)$ & $4(1.74+0.88)$ & $2(0.95+0.95)$ & $1(0.48+0.48$ \\
\hline HG21c-N & 4 & 256 & $115(41.12+7.47)$ & $61(20.81+7.47)$ & $49(16.67+6.28)$ & $6(2.78+1.23)$ & $4(1.58+0.92)$ & $1(0.29+0.29)$ & 0.00 \\
\hline HG21c-T & & & $147(54.62+9.11)$ & $75(27.56+8.20)$ & $59(20.22+6.76)$ & $39(13.93+4.50)$ & $12(4.55+2.03)$ & $1(0.29+0.29)$ & 0.00 \\
\hline HGn8E-N & 4 & 185 & $32(17.88+2.68)$ & $12(6.72+1.07)$ & $8(3.95+1.51)$ & $3(1.64+0.60)$ & $3(1.64+0.60)$ & $3(1.71+0.61)$ & $1(0.71+0.71$ \\
\hline HGn8E-T & & & $62(33.24+3.95)$ & $16(8.82+1.02)$ & $12(6.32+0.66)$ & $8(4.25+1.26)$ & $8(4.25+1.26)$ & $3(1.71+0.61)$ & $1(0.71+0.71$ \\
\hline
\end{tabular}

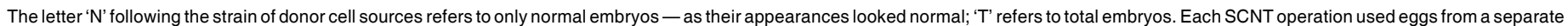
individual and GFP+ donor cells from a pool of embryos.

abnormal cloned embryos at GR showed unequal migration of the cells toward the vegetal pole of the egg. Upon finishing gastrulation, at 90 percent epiboly (EB), cells have completely migrated from the animal pole to the vegetal pole, and the three germ layers are formed. Except for the 16 percent rate of $\mathrm{HG} 21 \mathrm{C}$, only 3 to 5 percent of cloned embryos reached normal EB. At the EB stage, most of the abnormal cloned embryos showed lower cell densities than the normal embryos. The segmentation period follows; as cells progress in differentiation, they form somites and start organogenesis. By day 3, having finished organogenesis, the embryos hatch from the chorion and develop a swim bladder. At days 1 to 4, the number of cloned embryos dropped dramatically to 0.4 percent in the $\mathrm{HGn} 62 \mathrm{~A}$ and $\mathrm{HGn} 30 \mathrm{~A}$ lines. For the HGn28A and $\mathrm{HG} 21 \mathrm{C}$ lines, the number of cloned embryos remained at 2 to 3 percent at day 1 and dropped by half at day 4 . The cloned HGn8E embryos remained at 1.6 percent until day 4. As previously reported (Siripattarapravat et al., 2009b), we observed various degrees of abnormality in cloned embryos at days 1 to 4 . All of the normal cloned embryos started to eat at day 4. Only two fry from GFP+ donor cells of the HGn28A and HGn8E lines reached adult fish. We used a two-way analysis of variance (ANOVA) to analyze the data. The model was set for binomial distribution of the counting dataset under PROC GRIMMIX (SAS system). Since the variances are discrete in two developmental stages from others, i.e., the number of eating fry and adults, they were excluded from the statistical analysis.

Statistical analysis found no significant interaction between the sources of GFP+ donor cells and the numbers of cloned embryos at all developmental stages recorded. When contemplating donor cell individuals, and accounting for the total number of embryos from all developmental stages (from blastula to day 4), the HG21C donor cells had a significantly higher cloning efficiency than any other donor cells $(p<0.05)$. When comparing numbers of normal embryos, no difference was found among donor cells of all lineages.

\section{Discussion}

We found that the developmental capacity differed between cell lines when analyzed from the blastula to the hatched fry stages. All cell lines were capable of generating cloned fish, with the HG21C line being the most efficient.

Many cloned fish failed to develop normally, most likely due to failures of reprogramming. We speculate that no altered phenotypes were due to the transgene present in the fish lines used, since four out of the five lines harbored the inserted gene in the intronic region of the genome. The HG21C line however, had its transgene inserted into the Tcf7 gene (transcription factor 7) sequences. It is possible that this may have affected the reprogramming ability of the egg since Tcf7 is part of the Wnt signaling. This possibility is less likely since Lef1 gene acts in a redundant manner during embryogenesis and only Tcf7 homozygous mutants show abnormal development of the fins (Nagayoshi et al., 2008).

A potential confounding factor that could have negatively impacted the rate of normal fish generated, could be the use of UV

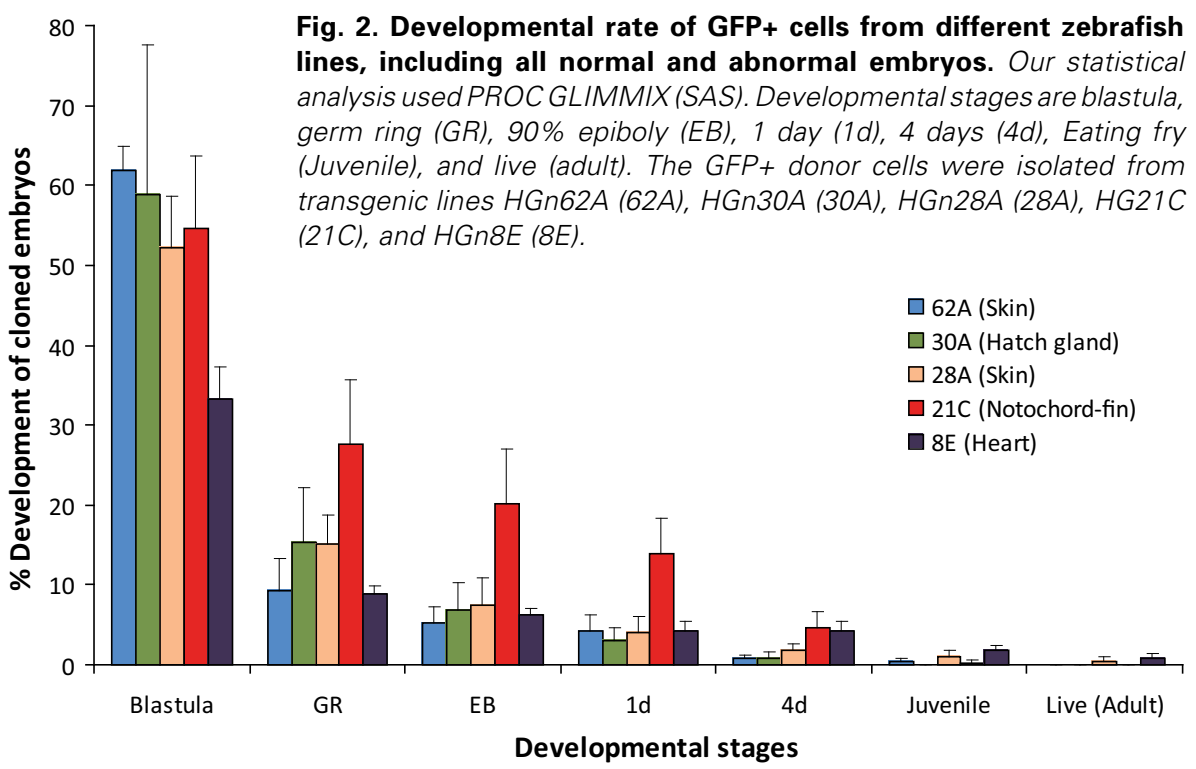


light we used to localize the DNA in the egg nucleus and to select transgenic cells. However, three pieces of evidence argue against such speculation. First, we ran control experiments in which, after we exposed eggs to UV light and used lasers to irradiate their cytoplasm, they were fertilized in vitro; still, healthy fish were generated after this manipulation. Second, our method explicitly minimized UV exposure to less than five seconds; and third, fresh donor cells were loaded every 30 minutes. Finally, if UV radiation could increase the rate of abnormalities, all of our experiments would be equally affected, since all five transgenic fish lines were subjected to the same treatment. Thus, we can conclude that UV exposure was not a confounding factor in the overall comparison of cloning efficiency among cell lines.

It has been demonstrated in several mammalian species that SCNT is possible with donor cells at either the G1/G0 or G2-M phase, but not at the S phase (Campbell et al., 1996; Cibelli et al., 1998; Egli et al., 2007; Wakayama et al., 1999). We did not test the cells for their stage in the cell cycle prior to SCNT; the cells used as donors may have been at different stages in the cell cycle. However, in an attempt to standardize our protocol, we purposely selected the smallest cells in the pool, likely selecting only cells in the G0 to G1 stage. Nonetheless, more work is needed to determine how different stages of the cell cycle affect cloning efficiency in zebrafish.

GFP+ cells in the HGn30A and HGn8E lines are distinctly specialized cells. Cells from the HGn30A line contain multiple cytoplasmic vesicles, possibly storing proteolytic enzymes produced from the cells of the hatch gland. Our injection technique delivered all cytoplasmic components, together with the nucleus, at the time of nuclear transfer. The components in those vesicles may negatively affect the reconstructed embryos and the capacity for nuclear reprogramming. GFP+ cells of the HGn8E line are heart muscle cells; some of them are multinucleated cells. It is possible that more than one nucleus was transferred, which may have caused ploidy abnormalities in the cloned embryos. In addition, muscle cells are known to continue to express musclespecific genes, possible making them more resilient to epigenetic modifications (Gao et al., 2003).

In mouse cloning, the observed abnormalities were due not only to epigenetic reprogramming, but also to karyotypic abnormalities from manipulating the donor nucleus (Wakayama and Perry, 2002). We did not analyze for karyotypes in the abnormal clone embryos. Therefore, we cannot rule out all possible causes of abnormalities in the clones.

In summary, we found that GFP+ cells isolated from the HG21C zebrafish line yielded the highest capacity for nuclear reprogramming following SCNT. A thorough analysis of the epigenetic signatures of these cells may help us elucidate specific factors that are responsible for their enhanced reprogramming capacity.

\section{Materials and Methods}

\section{Zebrafish strain}

The fish outcrossed between the Tubingen and $A B$ lines, called $T A B$, were used as female egg donors. Transgenic zebrafish (Nagayoshi et al., 2008) with a Tubingen long-fin background, expressing tissue-specific GFP (HGn30A-hatch gland, HGn28A and HGn62A-skin, HG21C-fin/ notochord, and HGn8E-heart) were used to isolate donor cells.

\section{Preparation of recipient eggs and donor cells}

The recipient eggs were obtained by a stripping technique (Westerfield, 1993). The eggs were immediately placed in Chinook salmon ovarian fluid (CSOF) (Siripattarapravat et al., 2009a). The eggs were stained with 50 $\mu \mathrm{g} / \mathrm{ml}$ Hoechst33342 for 20 minutes, as described previously (Siripattarapravat et al., 2009b), and kept in CSOF until used for nuclear transfer. The donor cells were freshly prepared from embryos at $24 \mathrm{hpf}$, raised at $28^{\circ} \mathrm{C}$. A fluorescence microscope was used to sort GFP+ embryos. For the HGn30A, HG21C, and HGn8E lines, the embryos were dissected and selected for the GFP+ tissues. For the HGn28A and HGn62A lines, the whole embryos were extracted from the yolk prior to use. Subsequently, embryos were briefly minced in LHC basal media and trypsinized (with 0.025 percent trypsin) at room temperature for 10 to 15 minutes. The activity of trypsin was then inhibited by using 5 percent fetal bovine serum in LHC. The cells were washed twice with LHC, and kept in DNACs medium (Siripattarapravat et al., 2009b) until used for nuclear transfer. In the case of the HGn30A and HGn8E lines, more than 20 embryos were utilized in each manipulation, as each embryo contained limited numbers of GFP-expressing cells. For other strains, only 5 to 10 embryos were used. The cell suspension was added to a new drop in a manipulation dish every 30 minutes to minimize repeated UV exposure of donor cells.

\section{Somatic cell nuclear transfer}

Nuclear transfer was performed as described previously (Siripattarapravat et al., 2009b), with minimal modifications. For enucleation, the DNA-stained egg's metaphase plate was ablated within the chorion using laser firing. We used an injection needle that was $8 \mu \mathrm{m}$ in diameter for all cell types except the HGn62A line, where we used a $9 \mu \mathrm{m}$ needle. Prior to injection, cells were selected for GFP expression and individually picked for nuclear transfer. The individual donor nucleus was then transferred to the egg through the micropyle (the sperm entry site). Reconstructed embryos were activated in 'embryo medium' (Westerfield, 1993) and allowed to develop. The developmental potential of cloned embryos were monitored and recorded every three hours after egg activation up to day 1 and continued daily until adulthood.

\section{Statistical analysis}

The developmental potential of cloned embryos was analyzed statistically using two-way ANOVA and tested for the effects of two factors: the types of donor cells and the number of live embryos at seven developmental stages. Since the response variable was the number of living embryos from the initial total of reconstructed embryos, we considered modeling the count nature of the data assuming a binomial distribution under PROC GLIMMIX (SAS Institute, 2008). Repeated measures analysis was considered for developmental stages which required the modeling of a covariance structure across time points. An autoregressive model for covariance structure was preferred, based on Akaike's information criterion values. Least squares means were estimated after back-transforming from the binomial distribution using a logistic link function. Means for the percentage of embryos obtained from each type of cell were compared for significant differences within each developmental stage using Fisher's protected LSD and alpha $<0.05$.

\section{Acknowledgements}

We thank: the Michigan Department of Natural Resources and the egg takers at the Little Manistee Weir for facilitating CSOF collection; The Royal Thai government and Kasetsart University for the studentship of K.S.; and J. Rigling and J. Stuewer for maintaining the zebrafish facility. This project was supported by the research fund endowed by the College of Veterinary Medicine, the Michigan State University Experimental Station, the Office of the Vice President for Research and Graduate Studies, the Michigan State University Foundation, the Naylor Family Foundation and the National BioResource Project from the Ministry of Education, Culture, Sports, Science and Technology of Japan. 


\section{References}

BOIANI, M., ECKARDT, S., SCHOLER, H.R. and MCLAUGHLIN, K.J. (2002). Oct4 distribution and level in mouse clones: consequences for pluripotency. Genes Dev 16: 1209-1219.

CAMPBELL, K.H., MCWHIR, J., RITCHIE, W.A. and WILMUT, I. (1996). Sheep cloned by nuclear transfer from a cultured cell line. Nature 380: 64-66.

CIBELLI, J.B., CAMPBELL, K.H., SEIDEL, G.E., WEST, M.D. and LANZA, R.P. (2002). The health profile of cloned animals. Nat Biotechnol 20: 13-14.

CIBELLI, J.B., STICE, S.L., GOLUEKE, P.J., KANE, J.J., JERRY, J., BLACKWELL, C., PONCE DE LEON, F.A. and ROBL, J.M. (1998). Cloned transgenic calves produced from nonquiescent fetal fibroblasts. Science 280: 1256-1258.

EGLI, D., ROSAINS, J., BIRKHOFF, G. and EGGAN, K. (2007). Developmental reprogramming after chromosome transfer into mitotic mouse zygotes. Nature 447: 679-685.

GAO, S., CHUNG, Y.G., WILLIAMS, J.W., RILEY, J., MOLEY, K. and LATHAM, K.E. (2003). Somatic cell-like features of cloned mouse embryos prepared with cultured myoblast nuclei. Biol Reprod 69: 48-56.

GURDON, J.B., ELSDALE, T.R. and FISCHBERG, M. (1958). Sexually mature individuals of Xenopus laevis from the transplantation of single somatic nuclei. Nature 182: 64-65.

GURDON, J.B., LASKEY, R.A. and REEVES, O.R. (1975). The developmenta capacity of nuclei transplanted from keratinized skin cells of adult frogs. $J$ Embryol Exp Morphol 34: 93-112.

GURDON, J.B. and MELTON, D.A. (2008). Nuclear reprogramming in cells. Science 322: 1811-1815.

GURDON, J.B. and UEHLINGER, V. (1966). «Fertile» intestine nuclei. Nature 210: 1240-1241.

HOCHEDLINGER, K. and JAENISCH, R. (2006). Nuclear reprogramming and pluripotency. Nature 441: 1061-1067.

KATO, Y., TANI, T. and TSUNODA, Y. (2000). Cloning of calves from various somatic cell types of male and female adult, newborn and fetal cows. J Reprod Fertil 120: 231-237.

KIMMEL, C.B., BALLARD, W.W., KIMMEL, S.R., ULLMANN, B. and SCHILLING, T.F. (1995). Stages of embryonic development of the zebrafish. Dev Dyn 203: 253-310.

LASKEY, R.A. and GURDON, J.B. (1970). Genetic content of adult somatic cells tested by nuclear transplantation from cultured cells. Nature 228: 1332-1334.

NAGAYOSHI, S., HAYASHI, E., ABE, G., OSATO, N., ASAKAWA, K., URASAKI, A., HORIKAWA, K., IKEO, K., TAKEDA, H. and KAWAKAMI, K. (2008).
Insertional mutagenesis by the Tol2 transposon-mediated enhancer trap approach generated mutations in two developmental genes: tcf7 and synembrynlike. Development 135: 159-169.

NG, R.K. and GURDON, J.B. (2005). Epigenetic memory of active gene transcription is inherited through somatic cell nuclear transfer. Proc Natl Acad Sci USA 102: 1957-1962.

NG, R.K. and GURDON, J.B. (2008). Epigenetic memory of an active gene state depends on histone H3.3 incorporation into chromatin in the absence of transcription. Nat Cell Biol 10: 102-109.

OBACK, B. (2009). Cloning from stem cells: different lineages, different species, same story. Reprod Fertil Dev 21: 83-94.

OBACK, B. and WELLS, D.N. (2007). Donor cell differentiation, reprogramming, and cloning efficiency: elusive or illusive correlation? Mol Reprod Dev 74: 646654.

RIDEOUT, W.M., 3RD, WAKAYAMA, T., WUTZ, A., EGGAN, K., JACKSONGRUSBY, L., DAUSMAN, J., YANAGIMACHI, R. and JAENISCH, R. (2000). Generation of mice from wild-type and targeted ES cells by nuclear cloning. Nat Genet 24: 109-110.

SANTOS, F. and DEAN, W. (2004). Epigenetic reprogramming during early development in mammals. Reproduction 127: 643-651.

SAS INSTITUTE INC. (2008). SAS/STAT® 9.2 User's Guide. Cary, NC: SAS Institute Inc.

SIRIPATTARAPRAVAT, K., BUSTA, A., STEIBEL, J.P. and CIBELLI, J. (2009a) Characterization and in vitro control of MPF activity in zebrafish eggs. Zebrafish 6: 97-105.

SIRIPATTARAPRAVAT, K., PINMEE, B., VENTA, P.J., CHANG, C.C. and CIBELLI J.B. (2009b). Somatic cell nuclear transfer in zebrafish. Nat Methods 6: 733 735

THUAN, N.V., KISHIGAMI, S. and WAKAYAMA, T. (2010). How to improve the success rate of mouse cloning technology. J Reprod Dev 56: 20-30.

WAKAMATSU, Y. (2008). Novel method for the nuclear transfer of adult somatic cells in medaka fish (Oryzias latipes): use of diploidized eggs as recipients. Dev Growth Differ 50: 427-436.

WAKAYAMA, T., RODRIGUEZ, I., PERRY, A.C., YANAGIMACHI, R. and MOMBAERTS, P. (1999). Mice cloned from embryonic stem cells. Proc Natl Acad Sci USA 96: 14984-14989.

WAKAYAMA, T. and YANAGIMACHI, R. (1999). Cloning of male mice from adult tail-tip cells. Nat Genet 22: 127-128.

WESTERFIELD, M. (1993). The Zebrafish book: a guide for the laboratory use of zebrafish (Brachydanio rerio). University of Oregon Press, Eugene. Or. 


\section{Further Related Reading, published previously in the Int. J. Dev. Biol.}

See our recent Special Issue Developmental Hematopoiesis

edited by Charles Durand, Tierry Jaffredo and Alexander Medvinsky at:

http://www.ijdb.ehu.es/web/contents.php?vol=54\&issue=6-7

Enhancing somatic nuclear reprogramming by Oct4 gain-of-function in cloned mouse embryos

Martin J. Pfeiffer, Sebastian T. Balbach, Telma C. Esteves, Nicola Crosetto and Michele Boiani

Int. J. Dev. Biol. (doi: 10.1387/ijdb.103197mp)

Uteroplacental vascular development and placental function: an update

Lawrence P. Reynolds, Pawel P. Borowicz, Joel S. Caton, Kimberly A. Vonnahme, Justin S. Luther, David S. Buchanan, Shireen A. Hafez, Anna T. Grazul-Bilska and Dale A. Redmer

Int. J. Dev. Biol. (2010) 54: 355-365

Yves Delage (1854-1920) as a forerunner of modern nuclear transfer experiments JEAN-CLAUDE BEETSCHEN and JEAN-LOUIS FISCHER

Int. J. Dev. Biol. (2004) 48: 607-612

Mammalian oocyte activation: lessons from the sperm and implications for nuclear transfer.

R Alberio, V Zakhartchenko, J Motlik and E Wolf

Int. J. Dev. Biol. (2001) 45: 797-809

Nuclear remodelling and early development in cryopreserved, porcine primordial germ cells following nuclear transfer into in vitro-matured oocytes.

L Liu, R M Moor, S Laurie and E Notarianni

Int. J. Dev. Biol. (1995) 39: 639-644

Does the chaperone heat shock protein hsp70 play a role in the control of developmental processes?

N Angelier, N Moreau, M L Rodriguez-Martin, M Penrad-Mobayed and C Prudhomme

Int. J. Dev. Biol. (1996) 40: 521-529

Developmental incompatibility between cell nucleus and cytoplasm as revealed by nuclear transplantation experiments in teleost of different families and orders.

S Y Yan, M Tu, H Y Yang, Z G Mao, Z Y Zhao, L J Fu, G S Li, G P Huang, S H Li and G Q Jin

Int. J. Dev. Biol. (1990) 34: 255-266

$$
5 \text { yr ISI Impact Factor }(2009)=3.253
$$

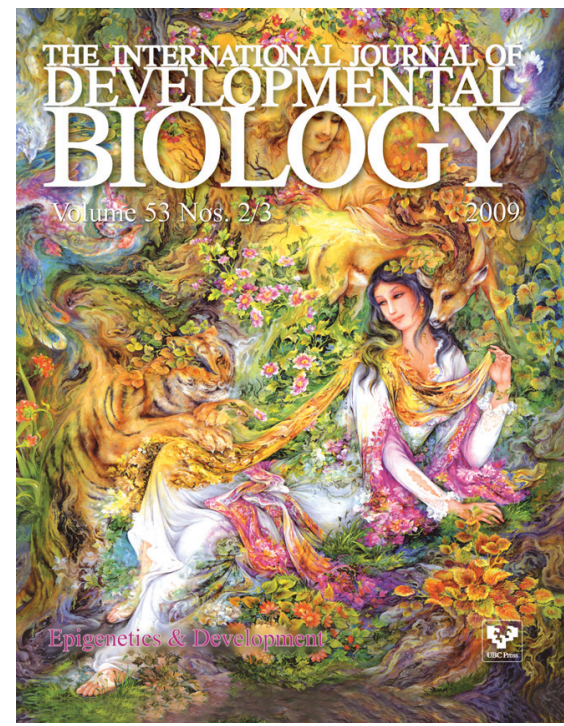

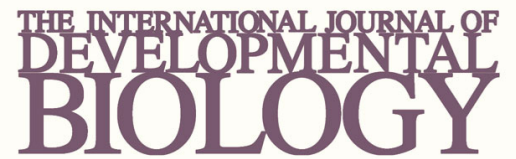

Volume 54 Nos. 6/7
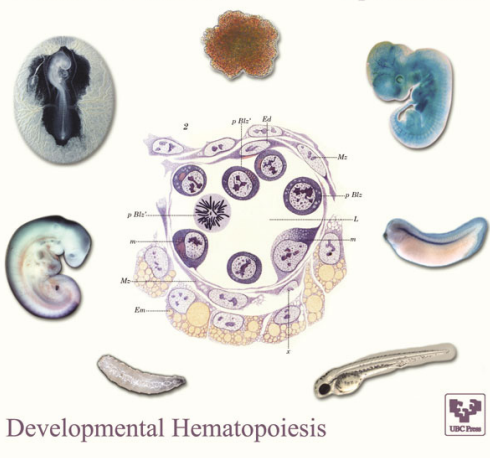

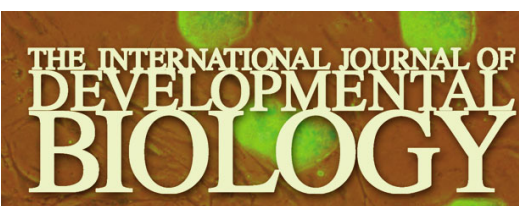

Volume 54 Nos. $11 / 12$

Special Issue

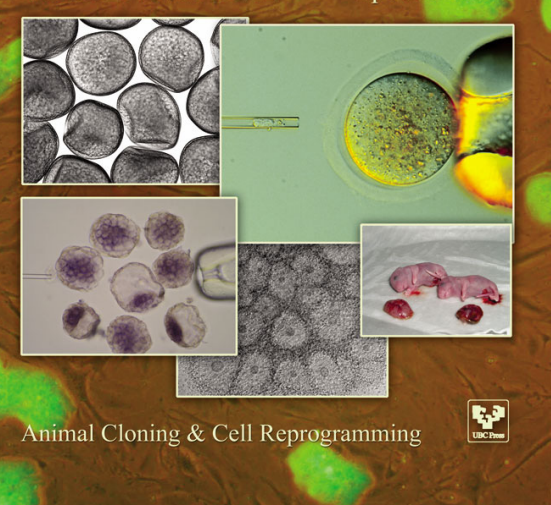

